\title{
THE STATUS OF MATRIMONIAL PROPERTY OWNERSHIP IN MIXED MARRIAGES
}

\author{
Sonny Dewi Judiasih* \\ Department of Civil Law, Faculty of Law Universitas Padjadjaran, Bandung \\ Jalan Dipati Ukur No. 35, Bandung, Jawa Barat 40132
}

\begin{abstract}
Many Indonesians have committed themselves into a mixed marriage, both in Indonesia and outside the country. Mixed marriage would mean that there are differing nationalities who abide under two different state laws and as consequence of this, issues of private international law in joint property would emerge. On the status of ownership on immovable assets such as land, the nationality principle must be paid attention to, because according to Indonesian law, only Indonesian citizens may have access to Land Ownership Rights. Thus, in mixed marriages, foreign spouses (husband or wife) may not have land ownership rights. Keywords: mixed marriage, marital property, ownership.
\end{abstract}

\section{Intisari}

Masyarakat Indonesia banyak yang melakukan perkawinan campuran, baik yang dilakukan di Indonesia maupun di luar negeri. Pelaksanaan perkawinan campuran menyebabkan adanya perbedaan kewarganegaraan dimana mereka tunduk pada sistem hukum yang berlainan sehingga melahirkan masalah hukum perdata internasional dalam pengaturan harta bersama. Mengenai status kepemilikan atas benda tidak bergerak seperti tanah, terdapat asas nasionalitas yang harus diperhatikan, yaitu hanya WNI saja yang boleh mempunyai Hak Milik Atas Tanah. Oleh karena itu, dalam perkawinan campuran, suami atau istri yang berkewarganegaraan asing tidak boleh mempunyai hak milik atas tanah.

Kata kunci: perkawinan campuran, harta bersama, hak milik.

\section{Pokok Muatan}

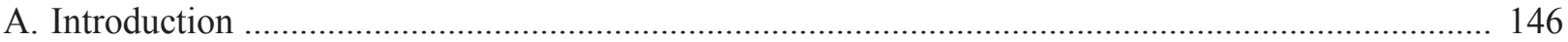

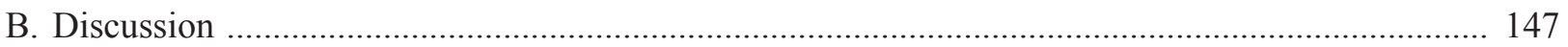

1. Status of Jointly Owned Property in Mixed Marriages ............................................................. 147

2. Ownership Status over Immovable Assets in Mixed Marriages .................................................. 149

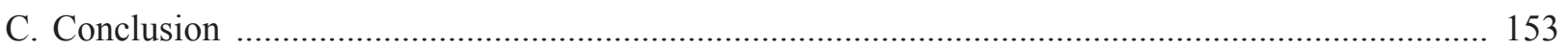




\section{A. Introduction}

Society is comprised of humans; humans as individuals or within groups which gather for a variety of needs and goals. These elements of society, day by day, always interacts with one another. ${ }^{1}$ One of the forms of relationship between individuals within a society is that of a woman and a man in a marriage. As a form of individual societal interactions within a state, the relationship must be governed by the state through a positive law. The existence of such laws, besides guaranteeing order and legal certainty, is a logical consequence of a rechtsstaat or a state based on law. Laws are needed to harmonize and regulate societal interactions; laws protects one's interests by allocating a form of power unto him/her to act upon his/her interests.

Within Article 28 paragraph (1) of the Fourth Amendment to the 1945 Indonesian Constitution (Undang Undang Dasar Tahun 1945) it is stipulated that every person shall have the right to establish a family and to procreate based upon a lawful marriage. ${ }^{2}$ Article 1 of the Indonesian Marriage Law states that a marriage is a physical and spiritual bond between a man and a woman husband and wife, having the purpose of establishing a happy and lasting family founded on the Belief in God Almighty. From this, stems an obligation for the husband and wife to help and complete each other, enabling them to develop their personalities in order to help attain spiritual and material welfare. ${ }^{3}$

A marriage creates legal consequences for the husband and wife, to name a few: the legal relationship between the husband and wide, joint matrimonial property, the standing and status of legal children, and also inheritance. The consequences of the Indonesian Marriage Law would only apply if the marriage was done legally, namely fulfilling the criteria set by Article 2 paragraph (1) and paragraph (2) of the Indonesian Marriage Law: when entered in accordance with the laws of the respective religions and beliefs of the parties and entered in a register in conformity to statutory regulations. ${ }^{4}$ As further elaboration of this Article, Article 4 of Presidential Instruction Number 1 of 1991 on the Compilation of Islamic Law (Kompilasi Hukum Islam or ' $\mathrm{KHI}$ ') states that a marriage is legal if it is done according to Islamic Law, ${ }^{5}$ similar to Article 2 paragraph (2) Marriage Law. Additionally, Article 5 paragraph (1) of the KHI states in order to maintain the orderliness of marriage, Muslim marriages has to be registered. ${ }^{6}$

When the marriage starts, the position of the man as the husband and the woman as the wife becomes fixed, and from that moment, the husband and wife receives certain rights and obligations in their marital relationship. ${ }^{7}$ One of the rights and obligations that emerge from marriage concerns matrimonial property. Matrimonial property are assets obtained by the husband and/or wife in a marriage intended to fulfil the family's needs, and in this case, it does not matter who produces more money because each person has the mutual obligation to find income for the family's welfare.

On the matter of asset control in marriage, a husband and wife are both in an equal position; this can be seen in Article 36 paragraph (1) of the Indonesian Marriage Law which stipulates that, on joint property, husband and wife may dispose of the joint property with mutual consent. ${ }^{8}$ Furthermore, Article 51 paragraph (1) of Law Number 39 of 1999

\footnotetext{
Mochtar Kusumaatmadja and B. Arief Sidharta, 2000, Pengantar Ilmu Hukum: Suatu Pengenalan Pertama Ruang Lingkup Berlakunya Ilmu Hukum, Alumni, Bandung, p. 14

Article 28 paragraph (1), the 1945 Constitution of the Republic of Indonesia.

Djuhaendah Hasan, 1988, Hukum Keluarga Setelah Berlakunya UU No. 1 Tahun 1974 (Menuju ke Hukum Keluarga Nasional), Armico, Bandung, p. 25.

Article 2 paragraph (1) and paragraph (2) of Law No. 1 of 1974 concerning Marriage (State Gazette of the Republic of Indonesia Year 1974 Number 1, Supplement to the State Gazette of the Republic of Indonesia Number 3019).

Article 4 Presidential Instruction Number 1 of 1991 concerning the Compilation of Islamic Law.

Article 5 paragraph (1) of Law No. 1 of 1974 concerning Marriage (State Gazette of the Republic of Indonesia Year 1974 Number 1, Supplement to the State Gazette of the Republic of Indonesia Number 3019).

Zahry Hamid, 1976, Pokok-Pokok Hukum Perkawinan Islam dan UU Perkawinan di Indonesia, Bina Cipta, Yogyakarta, p. 55.

Article 36 paragraph (1) Law No. 1 of 1974 concerning Marriage (State Gazette of the Republic of Indonesia Year 1974 Number 1, Supplement to the State Gazette of the Republic of Indonesia Number 3019).
} 
concerning Human Rights ('Indonesian Human Rights Law') states:

During marriage, a wife and husband have equal rights and responsibilities with regard to all aspects of marriage, contact with their children, and rights to joint control of assets. ${ }^{9}$ Indonesian Marriage Law divides property in a marriage into two types: jointly owned marital property (harta bersama or colloquially known as harta gono-gini) and property brought into the marriage or separate property (harta bawaan or harta asal). ${ }^{10}$ Joint property is property produced during the marriage between a husband and wife, ${ }^{11}$ whilst separate property is property brought by the husband and wife into the marriage. ${ }^{12}$

Being in an equal position, the husband and wife may conduct actions upon joint property based on mutual consent, whilst with separate property, the husband and wife have full rights to conduct legal actions on the state of their respective properties. The status of joint property in a marriage becomes very complex when factors which affects its existence, such as polygamy, mixed marriages, prenuptial marriage agreement (perjanjian kawin), or unregistered marriages (nikah siri) comes into play.

Many Indonesians have committed themselves into a mixed marriage, both in Indonesia and outside the country. Even though mixed marriages will eventually produce many problems, this does not deter people from getting married although they posses different nationalities. Mixed marriages are permitted in Indonesia based on Article 57 of the Indonesian Marriage Law.

What is meant by 'mixed marriage' in the Indonesian Marriage Law is a marriage between two persons who in Indonesia are subject to different laws due to difference of citizenship, whilst one of them is an Indonesian citizen. ${ }^{13}$ It stresses on the point of differing nationalities, whereby the groom/ bride is subject to different laws.

Problems that are likely to ensue in mixed marriages relates to the status of ownership and control of matrimonial property due to the conflict of laws, particularly on immovable assets such as land ownership rights. One of the principals embraced by Indonesian land law can be found within Law Number 5 of 1960 concerning Basic Regulations on Agrarian Law ('Indonesian Agrarian Law') is the nationality principle; this principle suggests that only Indonesian citizens may have ownership rights. This means that, other than Indonesian citizens, they cannot have ownership rights. ${ }^{14}$

The issue analyzed in this writing is the status of joint matrimonial property and its immovable assets in a mixed marriage.

\section{B. Discussion}

\section{Status of Jointly Owned Property in Mixed Marriages}

Mixed marriage between a man and a woman is subject to two different state laws will produce a number of Private International Law issues in family law which include the actual marriage problem, the parent's authority, the status of children, jointly owned matrimonial property and others.

Joint property in mixed marriages produces a complex problem as it involves different legal systems, namely national law, in this case the Indonesian Marriage Law and the law of the concerned state. If a mixed marriage is to be

Article 51 paragraph (1) Law Number 39 of 1999 concerning Human Rights (State Gazette of the Republic of Indonesia Year 1999 Number 165, Supplement to the State Gazette of the Republic of Indonesia Number 3886).

10 For more details, see Article 35 Law No. 1 of 1974 concerning Marriage (State Gazette of the Republic of Indonesia Year 1974 Number 1, Supplement to the State Gazette of the Republic of Indonesia Number 3019).

11 Article 35 paragraph (1) Law No. 1 of 1974 concerning Marriage (State Gazette of the Republic of Indonesia Year 1974 Number 1, Supplement to the State Gazette of the Republic of Indonesia Number 3019).

12 Article 35 paragraph (2) Law No. 1 of 1974 concerning Marriage (State Gazette of the Republic of Indonesia Year 1974 Number 1, Supplement to the State Gazette of the Republic of Indonesia Number 3019).

13 Article 57 Law No. 1 of 1974 concerning Marriage (State Gazette of the Republic of Indonesia Year 1974 Number 1, Supplement to the State Gazette of the Republic of Indonesia Number 3019).

14 For more details, see Article 21 paragraph (1) Law Number 5 of 1960 concerning Basic Regulations on Agrarian Law (State Gazette of the Republic of Indonesia Year 1960 Number 104, Supplement to the State Gazette of the Republic of Indonesia Number 2043). 
conducted in Indonesia, then the marriage and its consequences must abide Indonesian marriage laws. The Indonesian Marriage Law regulates that property obtained during marriage becomes joint property, even when only one person produces money or certain properties. ${ }^{15}$ Separate property however, is property obtained by the husband or wife before marriage. ${ }^{16}$

Sudargo Gautama states that the PIL principle used in the regulating marital property in mixed marriages subjects itself to the couple's legal domicile. ${ }^{17}$ AThis is conducted to respect the woman side in a marriage and also third party interests in a marriage, who receives protection when a couple's legal domicile is used. In other words, the third party may rely on marital property law in which the couple resides in.

The choice for legal domicile is refers to Hague Conference on Private International Law, more specifically the Convention on the Law Applicable to Matrimonial Property Regimes dated 14 March 1978. Article 3 of the Convention states the following: ${ }^{18}$

The matrimonial property regimes is governed by the internal law designated by the spouses before marriage. The spouses may designated only one of the following laws:

(1) The law of any state of which either spouse is a nation at the time of designation.

(2) The law of any state of which either spouse has his habitual residence at the time of designation,

(3) The law of the first state where one of the spouses establised a new habitual.

The law, thus, designated applies to the whole of their property. Nonetheless, the spouses, whether or not they have designated a law under the previous paragraphs, may designate with respect to all or some of the immovables, the law of the place where these immovables are situated. They may also provide that any immovables which may subsequently be acquired shall be governed by the law of the place where such immovables are situated.

According to the description above, it can be concluded that mixed marriages may gives the husband and wife the choice to choose which law will apply to them with respect to matrimonial property.

The husband and wife, based on the principle of equality in a marriage, conducts an agreement on which law will apply to their matrimonial property. The husband and wife, furthermore, must abide by the laws in which their marital property is located. The principle of equality also gives both parties an equal say on the legal actions conducted to their matrimonial property.

In court practice, data gathered shows that prenuptial agreements in mixed marriages need to be made so parties are aware of their respective rights and obligations at the time of marriage, and are able to anticipate what will happen to their matrimonial property and the rights and obligations towards their children when the marriage breaks up due to divorce. If a prenuptial agreement is not entered into, when the couple divorces the law applicable is the law the couple used to get married or the law used at the time of the marriage.

For husbands and wives who have not agreed on which laws will regulate their matrimonial property, the Convention's Article 4 states as following: ${ }^{19}$

If the spouses, before marriage, have not designated the applicable law, their matrimonial regime is governed by the internal law of the state in which both

\footnotetext{
Article 35 paragraph (1) Law No. 1 of 1974 concerning Marriage (State Gazette of the Republic of Indonesia Year 1974 Number 1, Supplement to the State Gazette of the Republic of Indonesia Number 3019).

16 Article 35 paragraph (2) Law No. 1 of 1974 concerning Marriage (State Gazette of the Republic of Indonesia Year 1974 Number 1, Supplement to the State Gazette of the Republic of Indonesia Number 3019).

Sudargo Gautama, 1980, Hukum Perdata Internasional Indonesia Jilid III Bagian 1, Alumni, Bandung, p.153.

Article 3 Convention on The Law Applicable To Matrimonial Property Regimes, $14^{\text {th }}$ March 1978.

Article 4 Convention on The Law Applicable To Matrimonial Property Regimes, $14^{\text {th }}$ March 1978.
} 
spouses establish they first habitual residence after marriage. Nonetheless, in the following cases, the matrimonial property regimes is governed by the internal law of the state of the common nationality of the spouses:

(1) where the declaration provided for in Article 5 has been made by that State and its application to the spouses is not excluded by the provisions of the second paragraph of that Article;

(2) where that State is not a Party to the Convention and according to the rules of private international law of that State its internal law is applicable, and the spouses establish their first habitual residence after marriage -

a) in a State which has made the declaration provided for in Article 5, or

b) in a State which is not a Party to the Convention and whose rules of private international law also provide for the application of the law of their nationality.

(3) where the spouses do not establish their first habitual residence after marriage in the same State.

If the spouses do not have their habitual residence in the same State, nor have a common nationality, their matrimonial property regime is governed by the internal law of the State with which, taking all circumstances into account, it is most closely connected.

The conclusion taken from the above article is that at the start, husbands and wives are given freedom to choose which laws apply to their marital property, however if they do not use this opportunity, laws of the country where the couple reside in to live their daily lives would apply.

Husbands and wives within a marriage may also conduct legal actions with third parties, including undertaking credit agreements and using their marital property as securities. In conducting legal actions with third parties, Article 9 of the Convention regulates as follows:
The effects of the matrimonial property regimes on the legal relations between a spouse and the third party are governed by the law applicable to the matrimonial property regimes in accodance with the convention. Nonetheless, the law of a contracting state may provide that the law applicable to the matrimonial property regimes may not be relied upon by a spouse agains a third party when either that spouse habitual residence in its territorry, unless any requirements of publicity or registrations specified by that law have been complied with, or the legal relations between that spouse and the third party arise at a time when the third party either knew or should have known of the law applicable to the matrimonial property regimes. The law of a contracting state where an immovables is situated may provide an analoguesrole for the legal relations between a spouse and a third party as regards that immovables. A contracting state may specify by declaration the scope of the second and third paragraphs of this article. ${ }^{20}$

The Convention also regulates marital property in mixed marriages in the form of lands; such could be found within Article 6 of the Convention which explicitly states that the law applicable for this matter is the law whereby the asset is obtained or the immovable asset is located. The Article stipulates that:

The spouses, whether or not they have designated a law under the previous paragraph or under Article 3, may designate with respect to all or some of the immovables, the law of the place where these immovables are situated. They may also provide that any immovables which may subsequently be acquired shall be governed by the law of the palce where such immovables are situated. ${ }^{21}$

\section{Ownership Status over Immovable Assets in Mixed Marriages}

Ownership over immovable assets such as land in Indonesia is regulated under the Indonesian Agrarian Law as a form of the unification of 
land laws in Indonesia and has applied since 24 September 1960. The Indonesian Agrarian Law gives guarantees equal opportunities to Indonesian citizens in obtaining rights over land and its benefits for him/herself or his/her family, as found within Article 9 paragraph (2) of the Indonesian Agrarian Law. $^{22}$

Land ownership by Indonesian citizens is among Indonesia's constitutional rights. Article 28 letter H paragraph (4) of the 1945 Indonesian Constitution stipulates that every person shall have the right to own personal property and such property may not be unjustly held possession of any party. ${ }^{23}$ Article 36 of the Indonesian Human Rights Law also states that every person has the right to own property, both alone and in association with others, for the development of himself, his family, nation, and society through lawful means. ${ }^{24}$ This right as an Indonesian citizen cannot be removed, reduced, or limited by any party except for firmly established circumstances as regulated under law.

All land ownership and land use must be based on authority as given and protected by law. The existence of a legal basis creates a concrete legal relationship between the land owner and the land they own. Such legal ownership gives authority to the land owner to own the land physically and allows for the use of that land in line with the regulations as set in the Indonesian Agrarian Law and other laws.

Land rights for private use is regulated under Article 16 paragraph (1) of the Indonesian
Agrarian Laws. Among the types of land rights, ownership rights is the strongest and most holistic right as land ownership rights gives authority to the holder of rights to freely act upon the land he/ she owns over an indefinite time. ${ }^{25}$

According to Article 21 paragraph (1) of the Indonesian Agrarian Law, only Indonesian citizens may have land ownership rights. ${ }^{26}$ This Article is a manifestation of the nationality principle adopted by the Indonesian Agrarian Law. As a sovereign territory, all areas within Indonesia's territory is an entity in which the Indonesian society have an eternal connection with. Thus the nationality principle has consequences towards land ownership rights in Indonesia, namely that only Indonesian citizens may have the fullest relation with the earth water and air space including the natural resources contained therein..$^{27}$

The applicability of the nationality principle adopted by the Indonesian Agrarian Law with respect to land ownership rights consequently implies the different treatment applied towards Indonesian citizens and foreign nationals. ${ }^{28}$ As a legal subject, foreign nationals may not have ownership over land that is strong, full, and inheritable. ${ }^{29}$

The nationality principle in the Indonesian Agrarian Law fully prohibits foreign nationals to have land ownership rights, permitted land rights for foreign nationals according to the Indonesian Agrarian Law includes the right of use over land (hak pakai atas tanah) and the right to lease land for building (hak sewa atas bangunan). ${ }^{30}$ The following elaborates the right of use as referred to

\footnotetext{
22 Law Number 5 of 1960 concerning Basic Regulations on Agrarian Law (State Gazette of the Republic of Indonesia Year 1960 Number 104 , Supplement to the State Gazette of the Republic of Indonesia Number 2043).

3 Article 28 letter H paragraph (4) of the 1945 Constitution of the Republic of Indonesia.

24 Article 36 Law Number 39 of 1999 concerning Human Rights (State Gazette of the Republic of Indonesia Year 1999 Number 165, Supplement to the State Gazette of the Republic of Indonesia Number 3886).

25 Article 16 paragraph (1) Law Number 5 of 1960 concerning Basic Regulations on Agrarian Law (State Gazette of the Republic of Indonesia Year 1960 Number 104, Supplement to the State Gazette of the Republic of Indonesia Number 2043).

26 Article 21 paragraph (1) Law Number 5 of 1960 concerning Basic Regulations on Agrarian Law (State Gazette of the Republic of Indonesia Year 1960 Number 104, Supplement to the State Gazette of the Republic of Indonesia Number 2043).

27 Article 9 paragraph (1) Law Number 5 of 1960 concerning Basic Regulations on Agrarian Law (State Gazette of the Republic of Indonesia Year 1960 Number 104, Supplement to the State Gazette of the Republic of Indonesia Number 2043).

28 Martin Roestamy, 2011, Konsep-Konsep Hukum Kepemilikan Properti Bagi Orang Asing (Dihubungkan dengan Hukum Pertanahan), Alumni, Bandung, p. 98.

9 Ibid. p. 204.

30 Article 42 letter b jo. Article 45 letter b Law Number 5 of 1960 concerning Basic Regulations on Agrarian Law (State Gazette of the Republic of Indonesia Year 1960 Number 104, Supplement to the State Gazette of the Republic of Indonesia Number 2043).
} 
by Indonesian Agrarian Law:

The right of use is the right to use and/ or to collect produce from, land directly controlled by the State or land owned by another individual which grants authority and obligations as determined in the relevant right-granting decree by the official who is authorized to grant it or as determined in the agreement with the owner of the land, where the agreement is not a land-lease agreement or land-exploitation agreement, given that everything is possible as long as it does not contradict the spirit and provisions of this Act. ${ }^{31}$

Whilst the right to lease land for building, according to Article 44 paragraph (1) of the Indonesian Agrarian Law gives authority to the holder of rights to utilize land owned by another for the purpose of building, by paying to its owner an amount of money as rent. ${ }^{32}$

Despite this, land ownership rights may still be possessed by a foreign nation, because in several circumstances foreign nationals can legally have legal land ownership rights. One of which through the fusion of assets in a marriage between an Indonesian citizen and a foreign nationals, or 'mixed marriage' as referred to in Article 57 of the Indonesian Marriage Law.

Marriage undertaken by Indonesian citizens, conducted legally according to applicable law, will bring legal consequences; this includes marriages between Indonesian citizens and foreign nationals who abide by different state laws. One of the consequences of a marriage is the fusion of assets between a wife and husband which then becomes marital property jointly owned by the husband and wife.

If a husband or wife of Indonesian citizenship buys land with right of ownership during the marriage, then this land will become marital property of the husband and wife. In effect, the land bought by the husband or wife of Indonesian citizenship will, according to law, be owned by his/ her spouse who is a foreign national. Because of this, marital property in mixed marriages causes foreign nationals to have similar authority and standing as Indonesian citizens to have marital property in the form of right of ownership. ${ }^{33}$

In overcoming this possibility, the Indonesian Agrarian Law requires foreign nationals who have land ownership rights due to the fusion of assets in a mixed marriage, to relinquish this right within a 1 (one) year time period after receiving the right. If after this time limit the right of ownership is relinquished, then that right is removed by law and the land falls to the state. Further elaboration of this could be found within Article 21 paragraph (3) of the Indonesian Agrarian Law:

A foreigner, following the entry into force of this Law has obtained the right of ownership by way of inheritance without a will or by way of joint ownership of property resulting from marriage and an Indonesian citizen holding a land ownership right who, following the entry into force of this Law, loses Indonesian citizenship is obliged to relinquish that right within one year following the date of the ownership right is acquire in the case of the former or following the date upon which Indonesian citizenship is lost in the case of the latter. If following the expiry of the said time period, the right is not relinquished, then the said right is nullified for the sake of law and the land falls to the State with the proviso that the rights of other parties which encumber the lands remain in existence. ${ }^{34}$

The relinquishment of the land ownership right could be done by way of selling or through grants (hibah).

\footnotetext{
$31 \quad$ Article 41 paragraph (1) Law Number 5 of 1960 concerning Basic Regulations on Agrarian Law (State Gazette of the Republic of Indonesia Year 1960 Number 104, Supplement to the State Gazette of the Republic of Indonesia Number 2043).

32 Article 44 paragraph (1) Law Number 5 of 1960 concerning Basic Regulations on Agrarian Law (State Gazette of the Republic of Indonesia Year 1960 Number 104, Supplement to the State Gazette of the Republic of Indonesia Number 2043).

33 Lies Adityawati, 2012, Kepemilikan Hak Milik Atas Tanah dalam Perkawinan Campuran Tanpa Perjanjian Kawin Ditinjau dari UUPA dan UU Perkawinan, Thesis, Fakultas Hukum Universitas Padjadjaran, Bandung, p. 90.

34 Law Number 5 of 1960 concerning Basic Regulations on Agrarian Law (State Gazette of the Republic of Indonesia Year 1960 Number 104, Supplement to the State Gazette of the Republic of Indonesia Number 2043).
} 
According to Article 20 paragraph (2) of the Indonesian Agrarian Law, right of ownership can change hand and be transferred to other parties. ${ }^{35}$ The change/transfer of rights means that the right of ownership over land is transferred to other parties because of a legal action. ${ }^{36}$ PThe referred legal actions can done through sales, exchanges, grants (hibah), the inclusion of the property to a company's equity (inbreng), auctions, division of joint rights, granting right to build or right of use over land, security rights (hak tanggungan) and granting power to give out security rights. ${ }^{37}$

One permissible legal action to prevent the fusion of assets $\mathrm{n}$ a mixed marriage is through the making of a prenuptial agreement. Prenuptial agreements can be held to regulate the consequences of marriage which will almost always be related to marital property. A prenuptial agreement or perjanjiian kawin is entered into by the contracting parties immediately before the celebration of the marriage. ${ }^{38}$ In relation to prenuptial agreements, Article 29 of the Indonesian Marriage Law states that:

At the time of or prior to the marriage performance, both parties may by mutual consent conclude an ante nuptial contract in writing, legalized by the registrar of marriage, where upon the contents shall also be binding on third parties in so far as third parties are affected. ${ }^{39}$

Prenuptial agreements in mixed marriages are based on the consent and agreement of both parties (the tobe husband and wife). The consent and agreement of both parties shows fairness as both parties have the same right to prepare and enter into a prenuptial agreement. Such is in line with the theory of justice as proposed by John Rawls who supposes two (2) important principles: the principle of equal liberty and the principle of equal opportunity. ${ }^{40}$

Prenuptial agreements are important to anticipate problems, particularly problems related to assets, thus when a marriage is terminated, most especially due to divorce, the best equitable solution for the husband and wife could be found. On this matter, it is interesting to also note a statement by G.W. Patton, "in marriage, as long as love persists, there is little need of law to rule the relation between husband and wife, but the solicitor comes in through the door as love flies out of the window". ${ }^{41}$

On the ownership of marital property, especially on land ownership rights in mixed marriages, there is the possibility that there will be problems if the mixed marriage couple gets a divorce, because at the end they have to divide their jointly owned marital property. This should not be problem as long as the parties do not have any dispute over the joint ownership of marital property and that the property legally belongs to the mixed marriage couple. If they do not, the land ownership right (part of their marital property) which uses the name of the Indonesian spouse, can finally be divided according to the Indonesian Marriage Law. The division could be done through the selling of land whereby the proceeds could be divided into two for each party or could also be done through the division of land. In dividing land, the foreign national will receive his/her part of the land and only has 1 (one) year over the land's ownership rights, then he/she must relinquish his/her right over the land according to under Article 21 paragraph (3) of the Indonesian Agrarian Law. The relinquishment of right is done throught the act of selling or giving the rights of ownership over the land away.

\footnotetext{
35 Article 20 paragraph (2) Law Number 5 of 1960 concerning Basic Regulations on Agrarian Law (State Gazette of the Republic of Indonesia Year 1960 Number 104, Supplement to the State Gazette of the Republic of Indonesia Number 2043).

Muhamad Yamin Lubis and Abd. Rahim Lubis, 2010, Hukum Pendaftaran Tanah, Mandar Maju, Bandung, p. 30.

40 John Rawls, 2006, Teori Keadilan, Dasar-Dasar Filsafat Politik untuk Mewujudkan Kesejahteraan Sosial dalam Negara (trans: Uzair Fauzan dan Heru Prasetyo), Pustaka Pelajar, Yogyakarta, p. 361.

41 G. W. Patton, 1951, A Text Book of Jurisprudence, Oxford Clarendon Press, London, p. 53.
} 
Forms of agreements which indirectly transfers land ownership rights to foreign nationals include Land Ownership Agreement (Perjanjian Pemilikan Tanah or PPT) and nominee arrangements in a Land Ownership Agreement whereby the Indonesian citizen admits that the land registered under his/her name does not belong to him/her, but to the foreign national who has provided funds to buy the land ownership rights including structures on it. The Indonesian citizens then gives irrevocable authority to the foreign national to conduct any legal action towards the land ownership rights and its structure(s).

Based on the above, there has been several practice of abuses with nominee agreements such as this. By using the Indonesian citizen as a trustee or nominee is an offence as its substance conflict with the Indonesian Agrarian Law, especially Article 26 paragraph (2):

Every sale/purchase, exchange, gift, and bequest by a will and every other acct which are intended to either directly or indirectly transfer an ownership right to a foreigner or to a person of Indonesian citizenship who concurrently holds foreign citizenship or to a corporate body other than those stipulated by the Government in line with paragraph (2) of Article 21 shall be nullified for the sake of law and the land in question shall go to the State with the understanding that any other parties' rights which encumber the land shall remain in existence and that all the payments which the owner of the land may have received cannot be reclaimed. ${ }^{42}$
Consequently, nominee agreements gives Indonesian citizens and foreign national in a mixed marriage the right to own land by registering that land under the spouse holding Indonesian citizenship who has been appointed as nominee. The Indonesian citizen's name is used to enable him/her to buy land whereby funding originates from the parties involved in the mixed marriage.

\section{Conclusion}

The standing of marital property in mixed marriages strongly relates to the location whereby the marriage is carried out. If it is carried out in Indonesia then the applicable law is the Indonesian marriage law, but if carried outside the Indonesian territory then the applicable law is the law where the marriage is carried out. Because mixed marriage incorporates foreign elements, towards marital property, the Convention on The Law Applicable To Matrimonial Property Regimes would apply.

The status of ownership over immovable assets in a mixed marriage cannot be owned the husband and wife in that marriage, except if a prenuptial agreement is entered into. Even though one of persons in a mixed marriage is an Indonesian citizens, that Indonesian citizen cannot buy land with rights of ownership over the course of the marriage because the land will be owned jointly with the foreign national they married. This conflicts with the nationality principle which states that only Indonesian citizens may have land ownership rights.

\section{BIBLIOGRAPHY}

\section{A. Books}

Gautama, Sudargo, 1980, Hukum Perdata Internasional Indonesia Jilid III Bagian 1, Alumni, Bandung.

Hasan, Djuhaendah, 2000, Hukum Keluarga Setelah Berlakunya UU No. 1/1974 (Menuju Ke Hukum Keluarga Nasional), Armico,
Bandung.

Hamid, Zahry, 1976, Pokok-Pokok Hukum Perkawinan Islam dan UU Perkawinan di Indonesia, Bina Cipta, Yogyakarta.

Kusumaatmadja, Mochtar dan B. Arief Sidharta, 2000, Pengantar Ilmu Hukum: Suatu Pengenalan Pertama Ruang Lingkup

\footnotetext{
42 Article 26 paragraph (2) Law Number 5 of 1960 concerning Basic Regulations on Agrarian Law (State Gazette of the Republic of Indonesia Year 1960 Number 104, Supplement to the State Gazette of the Republic of Indonesia Number 2043).
} 
Berlakunya Ilmu Hukum, Alumni, Bandung.

Lubis, Muhamad Yamin and Abd. Rahim Lubis, 2010, Hukum Pendaftaran Tanah, Mandar Maju, Bandung.

Patton, G.W, 1951, A Text Book of Jurisprudence, Oxford Clarendon Press, London.

Roche, Evita M. and David C. Simmonds, 1988, Marriage Contract, The Carswell Company Limited, Ontario, Canada.

Rawls, John, 2006, Teori Keadilan, DasarDasar Filsafat Politik untuk Mewujudkan Kesejahteraan Sosial dalam Negara. (trans: Uzair Fauzan dan Heru Prasetyo), Pustaka Pelajar, Yogyakarta.

Roestamy, Martin, 2011, Konsep-Konsep Hukum Kepemilikan Properti Bagi Orang Asing (Dihubungkan dengan Hukum Pertanahan), Alumni, Bandung.

\section{B. Research/Thesis}

Adityawati, Lies, 2012, Kepemilikan Hak Milik Atas Tanah dalam Perkawinan Campuran Tanpa Perjanjian Kawin Ditinjau dari UUPA dan UU Perkawinan, Thesis, Faculty of Law Universitas Padjajaran, Bandung.

\section{Legislations}

The1945 Constitution of the Republic of Indonesia. Law Number 5 of 1960 concerning Basic Regulations on Agrarian Law (State Gazette of the Republic of Indonesia Year 1960 Number 104, Supplement to the State Gazette of the Republic of Indonesia Number 2043).

Law No. 1 of 1974 concerning Marriage (State Gazette of the Republic of Indonesia Year 1974 Number 1, Supplement to the State Gazette of the Republic of Indonesia Number 3019).

Law Number 39 of 1999 concerning Human Rights (State Gazette of the Republic of Indonesia Year 1999 Number 165, Supplement to the State Gazette of the Republic of Indonesia Number 3886).

Presidential Instruction Number 1 of 1991 concerning the Compilation of Islamic Law.

\section{Other Documents}

Convention on the Law Applicable to Matrimonial Property Regimes, 14 March 1978. 